\title{
Legal Protection of Registered Mark Owner in Indonesian
}

\author{
Abdul Hakim \\ Faculty of Law, University of Muhammadiyah Sumatera Utara, Medan, Indonesia \\ abdulhakimsiagian@umsu.ac.id
}

\section{Abstract}

Before the laws of mark well-known in Indonesia, the Indonesian people were happy to participate their creativity in being invited by others, feeling proud of the copyrighted work was finally followed by many people, but following the development of the era as it is now imitating other people's work is used as business object and profitable itself, so that in accordance with its development the owner is considered disadvantaged by the act of imitating his work because it involves business interests and/or profit and gain. Research is a basic tool in the development of science and technology. This research aims to reveal the truth systematically, methodologically, and consistently through the process of research analysis and construction of data that has been collected and processed. The problem in this research is the problem of protection of registered mark owners in Indonesia. The result of this research is mark rights are an important part of marks, therefore mark rights are privileges for their owners, brands are important in the marketing and advertising world, and therefore specifically related to the deadline for protection of registered marks for 10 years, the time limit which is deemed short can be extended, the replacement in accordance with the registered mark is actually used in goods/services and they needed and/or sold and is still on the market and is still distributed.

Keywords

legal protection; mark;

registered

\section{Introduction}

Basically before the law of mark familiar in Indonesia, Indonesian people in general are happy if their creativity is followed by other people, feeling proud of the ownership of works are finally followed by many people, but as the times evolve like today the imitation of someone's works are used as business objects and benefit themselves, eventually the mark owner is considered to be disadvantaged by the act of imitation of his work because it involves business interests and/or profit and loss. Developments related to the protection of a person's or group's work to trademark ownership. The mark ownership is now the most important thing in terms of product introduction and/or someone's work too many people, the mark is also a differential between one works to another.

"Intellectual property rights are the rights of a creation; art, technology, or ideas that are personal to the creator and cannot be denied the existence. A person's work must be protected because it will benefit not only for him but also for all humanity". "Intellectual property rights are made by spending a lot of energy, time, thought, intuition and even cost, the existence of these sacrifices make these sacrifices make the work produced has value. If seen with the economic benefits that can be used, the inherent economic value fosters the concept of wealth on intellectual works".

"Intellectual property rights are private rights, such as a person is free to submit an application or registration of his intellectual work to get protection or not. Exclusive rights 
granted by the state to the creator or related rights holders are intended as a tribute to the results of their creativity and to stimulate others to develop further". Indonesia, which is classified as a developing country in Southeast Asia, has resulted in many developments from the outside world who want to enter Indonesia or even force them to enter Indonesia. The modernization era which is marked by the rapid development of information and technology resulting in an increase in one's curiosity about various forms of information (Prasetyo, 2019). Indonesia as part of the international community through Law No. 7 of 1994 has ratified the Agreement on the Establishment of the World Trade Organization which was formed through an agreement on trade tariffs. "The endorsement is based on the awareness of opportunities and challenges arising from the advancement of science, technology, and information that have been able to break through national boundaries, along with their social, cultural, economic and legal instruments". "Agreements concerning aspects of HKI (Hak Kekayaan Intelektual = IPR (Intellectual Property Rights) ) trade include, copyrights, brand rights, geographical indications, industrial designs, patents, integrated circuit layout, protection of confidential information, control of unfair business competition practices in license agreements".

Based on these IPR aspects, there are Mark Rights whose legal rules in Indonesia are regulated in Act Number 15 of 2001 concerning Marks and amended by Law No 20 of 2016 into Mark and Geographical Indications Law (hereinafter referred to as Mark law). Mark rights, in this case, are part of other intellectual property rights that always develop following the times, strongly influenced by social, economic and technological factors, because the more advanced the technology of a country, the more violations are committed.

Based on the understanding of the mark is a sign in the form of images, names, words, letters, numbers, composition, or a combination of these elements that have the power of differentiation and are used in trading activities of goods and services. Mark is a distinguishing mark of goods or services for one company with another company. As a sign of differentiation, brands in a clarification of goods/services must not have in common between one and the other, both in whole and in their items. "The definition of equality in its entirety is that if it has similarities in terms of origin, nature, method of manufacture and intended use. While the meaning of equality, in essence, is that if it has an equation in the form equation, the equation of how to place it, the form of the equation and how to place it, the equation of speech sounds". One of the actual developments that have received close attention in the past ten years and the tendency that will continue to take place in the future is the increasingly widespread flow of globalization, both in the social, economic, cultural and other fields of life. The development of information technology and transportation has made activities in the trade sector increase rapidly even has placed the world as a single market together.

The era of global trade can only be maintained if there is a fair business competition climate. Here the mark plays a very important role that requires an adequate regulatory system. Based on these considerations and in line with international treaties that have been ratified by Indonesia as well as experience implementing brand administration, refinement of the mark law is Law No. 19 of 1992 (1992 State Gazette Number 81) as amended by law No. 14 Year 1997 (State Gazette Year 1997 Number 31) as amended by Act Number 15 of 2001 concerning Mark and amended by Law No. 20 of 2016 concerning Mark becoming Marks and Geographical Indications (hereinafter referred to as Mark Law).

Law No. 20 of 2016 in Article 1 (paragraph 1) states mark means any sign capable of being represented graphically in the form of drawings, logos, names, words, letters, numerals, colors arrangement, in 2 (two) and/or 3 (three) dimensional shape, sounds, holograms, or 
combination of 2 (two) or more of those elements to distinguish goods and/or services produced by a person or legal entity in trading goods and/or services. "The right mark is a special right granted by the government to the brand owner, to use the mark or to give permission to use it to others, the mark is very important in the world of marketing and advertising because the public very often associates an image, quality, reputation of goods and services with certain meek. A mark can be a commercially valuable asset and a company's mark is often more valuable than the company's real assets. The mark is also useful for consumers to even buy a certain product in view of the mark, because they think the mark is of high quality or safe for consumption because of the reputation of the mark. If a company uses a mark from another company, consumers might feel cheated because they buy a lower quality product".

Based on this, the mark must be a concern for the government to support national and international economic development, bearing in mind that the country of Indonesia is a country that is widely sought by national and international businessmen, therefore good protection of marks is a concrete step by the government in supporting development national economy. At present, we see that there are many brands circulating in the national market where one mark and another have similarities, both in common and in common in their posts, and this is an act that is clearly detrimental to the State and the business owners of the mark rights. Based on this, related to the mark which is a form of someone's creation that must be protected because the mark is an intellectual property that has economic meaning for the creator. Marks are also not immune from acts in which the object can be used by other parties, both Equality in principle or equality in its entirety, where violations that occur in the trademark rights over marks are unauthorized use. If it is examined from the perspective of marks laws, it is clear that the act of using the trademark without permission can be detrimental to the trademark rights holder for the mark used.

Based on the explanation above and related to the title of the study: legal protection for registered mark owners in Indonesia, the focus of author's problem in this study is how the legal protection for registered mark owners in Indonesia? So that later will be found legal protection for mark registered in Indonesia

\section{Research Method}

The normative legal research method (normative research) is the method used in writing this scientific work. According to the type and nature of the research, the data source used in this paper is secondary data consisting of primary legal material in the form of; the laws and regulations relating to the theme of the discussion. The secondary legal materials in this study include; books, scientific journals, papers and scientific articles that can provide explanations and or lead to primary legal material. And the tertiary legal material in the form of the Big Indonesian Dictionary (KBBI) and others in finding definitions of terms in discussing mark in Indonesia.

The procedure used to collect data in this research is in the form of documentation in the form of notes or quotations, search of legal literature, books and others related to the identification of problems in the research referred to by means of offline and online. The approach used in this research is to use the statutory approach. Then the analysis of legal material is carried out by using a content analysis method (content analysis method) which is carried out by describing the material of the legal event or legal product in detail in order to facilitate interpretation in the discussion. 


\section{Discussion}

\subsection{Legal Protection for Registered Mark Owner in Indonesia Related Mark Regulations in Indonesia}

"Mark is something (picture or name) capable to use to identify a product or company characteristic in market". Usually a person who has a mark for his creation is relatively trying to make the mark of his creation not copied by other people and or entrepreneurs, because if we trace back the process related to making a mark and then raising the mark is not an easy thing for business actors and or mark owners, of course it requires a great sacrifice. Discussion of mark rights, the mark law states that the mark rights are the special rights of money granted by the government to the mark owner to use the mark or give permission to use it to others, this is certainly different from copyright, and the mark must be registered first first in the general list of mark.

Marks are any sign capable of being represented such as picture, name, words, letters, numerals, arrangement, or combination from those elements to distinguish used by a person or legal entity in trading goods and/or services. Mark is a sign to distinguish goods and services for a company and others. As a sign of differentiation, marks in a clarification of goods/services must not have in common between one and the other, both in whole and in their items. The definition of equality in its entirety is that if it has similarities in terms of origin, nature, method of manufacture, and intended use. While the meaning of equality in essence is that if it has an equation in the form equation, the equation of how to place it, the form of equation and how to place it, the equation of speech sounds.

One of the actual developments that received close attention in the past last year and which will continue in the future is the increasingly widespread globalization, both in the social, economic and cultural fields in other fields. The development of information technology and transportation makes activities in the trade sector increase and develop by making the world a single market together.

Global era trade just can be maintained if there is a fair business competition climate. Here the brand plays a very important role that requires an adequate regulatory system. Based on these considerations and in line with international treaties that have been ratified by Indonesia and experience implementing mark administration, Completion of mark law, namely Law No. 19 of 1992 (Statute Book No. 81 of 1992) as amended by Law No. 14 of 1997 (Statute Book No. 31 of 1997) as amended by Law No. 15 of 2001 concerning Mark and amended by law No. 20 of 2016 concerning Mark into Mark and Geographical Indications law (hereinafter referred to as Mark Law).

Intellectual Property Rights Consultant, Mudiardjo, explained that, when the company sells products and/or services, the company must register its mark based on the class of goods and services. Law No. 20 of 2016 in Article 1 (paragraph 1) states the mark is a sign that can be displayed graphically in the form of images, logos, names, words, letters, numbers, color arrangements, in the form of 2 (two) dimensions and/or 3 (three) dimensions, holographic sound or a combination of 2 (two) or more of these elements to distinguish goods and/or services produced by persons or legal entities in the trading of goods and/or services.

The right of mark is a special right granted by the government to the mark owner, to use the mark or to give permission to use it to others, the mark is very important in the world of marketing and advertising because the public very often associates an image, quality, reputation of goods and goods. With certain meek. A mark can be a commercially valuable asset and a company's mark is often more valuable than the company's real assets. The mark 
is also useful for consumers to even buy a certain product in view of the mark, because according to them the mark is of high quality or safe to be consumed because of the reputation of the mark. If a company uses a mark from another company, consumers might feel cheated because they buy a lower quality product.

Based on this, the mark must be a concern for the government to support national and international economic development, bearing in mind that the country of Indonesia is a country that is widely sung by national and international businessmen, therefore good protection of brands is a concrete step by the government in supporting development national economy. At present, we see that there are many mark circulating in the national market where one mark and another have similarities, both in common and in common in their posts, and this is an act that is clearly detrimental to the State and the business owners of the trademark rights. Based on this, related to the mark which is a form of someone's creation that must be protected because the mark is an intellectual property that has economic meaning for the creator. This mark does not escape the acts in which the object can be used by other parties, either Equality in essence or equality in its entirety where violations that occur in the trademark rights over the mark are unauthorized use. This act can be detrimental to the mark right holder for the trademark used.

\subsection{Mechanism dan Process of Mark Registration in Indonesia}

\section{a. Mark Registration with Declarative System}

"Declarative system is a registration system that only raises the assumption that there is a right as the first user of the mark concerned. The declarative system is considered less guarantee legal certainty than the constitutive system based on the first registration that provides more legal protection. The first registrar system is also called the first to file principle. That is, the registered mark is the one who qualifies and is the first. Not all brands can be registered. Trademarks cannot be registered on the basis of an application submitted by an applicant in bad faith. An applicant having a bad faith is an applicant who registered his trademark improperly and dishonestly, there are hidden intentions such as piggybacking, imitating, or plagiarizing of fame causing unfair competition and deceiving or misleading consumers".

\section{b. Registration of Brand with a constitutive system}

"Mark with a constitutive system, registration is a must in order to obtain trademark rights. Without registration the State will not grant mark rights to the mark owner. This means that without registering a mark, a person will not be given legal protection by the State if the mark is imitated by someone else. Registration of mark used in Indonesia since Law Number 19 of 1992 is a constitutive system. In this constitutive system, legal protection is based on the first registrant in good faith. This is also as stated in Article 4 of Law Number 15 Year 2001 which states that mark cannot be registered by applicants who are not in good faith". It means that in Law Number 15 of 2001 the Constitutional Registration system is adopted.

\section{c. Mark requirements that must be registered}

People can apply for trademark registration directly or can use the IPR consultant's authority to the Director General of IPR or through the regional office of the Ministry of Law and Human Rights, but what must be remembered about the requirements for obtaining mark protection under Law Number. 15 of 2001 concerning brands, that mark cannot be listed if 
1. An application submitted by an applicant in good faith; Article 4

2. Contrary to the prevailing laws and regulations, religion, morality or public order; Article 5 (a)

3. Has no differentiation aspect; Article 5 (b)

4. Public; Article 5 (c)

5. A description or connection related with the goods or services requested for registration

Mark is rejected if it has the following matters as stated in article 6 of law number 15 of 2001 concerning Mark

1. Have similarities in principle or in whole with other parties' marks that have been registered earlier; Article 6 paragraph 1 (a).

2. Have similarities in principle or the whole with other well-known party marks: Article 6 paragraph 1 (b). 3

3. Have similarities in principle or in whole with geographic indications that are well known: Article 6 paragraph 1 (c)

4. Have similarities in principle or in whole with well-known geographical indications: Article 6 paragraph 1 letter (c)

Because the rights to mark ownership are exclusive where the owner of the mark can do the following things:

1. The right to use its own mark.

2. Right to transfer to other parties.

3. The right to give permission to other parties to use the mark.

4. The right to extend legal protection for the mark.

5. The right to sue and/or sue both civil and criminal cases with other parties who use their trademarks without permission.

6. The right to get legal protection from other people's claims on the mark

How to apply for registration if the registrant is a legal entity

1. To fill in 4 (four) forms in Indonesian and type neatly.

2. To attach photos of ID cards of directors, power of attorney (if using power of attorney), a statement that the mark does not copy, brand etiquette (twenty-four pages) in Min size. 2x2 cm and Max. 9x9 cm.

3. A photocopy of company establishment deed authorized by a notary does not need to be authorized or legalized a notary if it is in the form of an additional state news / TBN RI.

4. Photocopy of NPWP of the Company

Marks must represent a sign that can be included on concerned goods or pack of the stuff. If a product produced by the company does not have the power of differentiation, then it is considered not a mark. Therefore, not all marks that meet the distinguishing features can be registered as marks. An application for registration of a mark that is filed by an applicant whose intent is not also cannot be registered.

Article 4 of Law Number 15 Year 2001 Concerning Mark states that a mark cannot be registered on the basis of an application submitted by an applicant in bad faith. With this provision, it is clear that a mark cannot be registered and rejected if the owner has a bad 
intention. In addition, according to Article 5 of Law Number 15 Year 2001 Concerning Mark that a mark cannot be registered if the mark contains one of the elements below. Contrary to applicable laws, religious morality, decency, or public order:

1. Has no distinctive distinguish

2. Has become public property; or

3. A description or related to the goods or services for which registration is requested

Provisions in Article 6 of Law Number 15 Year 2001 regarding Mark which regulates the mark being rejected. An application for registration of a mark must be rejected by the Directorate General of Intellectual Property Rights if the mark:

1. Have similarity in principle or in whole with other parties' marks that have already been registered for similar goods and/or services

2. Have similarity in principle or in whole with other parties' well-known brands for similar goods and or services

3. Has similarity in principle or in whole with familiar geographical indications

According to Sudargo Gautama, the application for mark registration must also be rejected by the Directorate General of Intellectual Property Rights, if the mark is

1. To resembles the name of a famous person, photo, or the name of a legal entity used as a trademark and registered in the General Register of Marks owned by others, except with the written consent of the entitled

2. An imitation or to resemble the name or abbreviation of the name, flag, symbol or symbol or emblem of a state or national institution (including community organizations or social political organizations) or international, except with the written consent of the competent authority

3. An imitation or to resemble an official mark or seal or stamp used by a state or Government institution, except with the written approval of the competent authority

Thus, from the provisions above, not all marks can be registered as marks. Only signs that meet the requirements below can be registered as marks:

Has a distinctive distinguish

1. The sign on a goods or service which can be in the form of pictures (paintings), names, words, letters, numbers, color arrangements or combinations of these elements

2. The sign is not contrary to the applicable laws and regulations, religious morality, decency, or public order; not a sign of being public and not public property; or does not constitute information or relate to the goods or services for which registration is requested

3. The mark also has no similarities with other registered brands, well-known brands, or known geographical indications

4. Does not constitute, resemble or duplicate other marks owned by a particular institution or country.

\section{d. Application for Mark Registration}

There are two types of application for trademark registration, namely:

1. Ordinary or common. Application for registration in the normal way is done because the trademark requested registration has never been registered at all in the manner as described above for local trademark registration for individuals or business entities. 
2. Priority Right. Application for registration with priority rights is made because the mark to be registered in Indonesia has already been registered in another country.

The conditions are the same as regular registration but there is a timetable according to Article 11 of Law no. 15 of 2001 that registration with priority rights must be submitted no later than 6 (six) months from the date of receipt of the application for registration of a mark (Filling date) for the first time in that foreign country and that country must be a member Paris Convention For The Protection Of Industrial Property atau anggota Establishing The World Trade Organization.

Regarding the requirements and procedures for applying for trademark registration, are regulated in Article 7 through Article 17 of Law Number 15 Year 2001 concerning Marks and set it in Goverment Regulation Number 23 Year 1993 concerning Procedure for Application for Mark Registration. The application for registration of a mark is submitted in writing in the Indonesian language to the Directorate General of Intellectual Property Rights by filling in the form and stating the type of goods and / or services as well as the class for which registration is requested.

The application for registration of the mark must be signed by the applicant or his/her proxy. The applicant consists of one person or several people together, or a legal entity. An application submitted by an applicant residing or permanently domiciled outside the territory of the Republic of Indonesia must be submitted through his attorney in Indonesia and declare and choose the residence of the power of attorney as Indonesia's legal domicile.

Article 11 of Law Number 15 Year 2001 Concerning Trademark Licensing Registration of Company Representatives with Priority Rights Must Be Licensed Period 6 (six) for the member of Paris Convention for the Protection of Industrial Property or a member of the Agreement Establishing the World Trade Organization.

This provision is intended to accommodate the interests of countries which are only one of the members of the Paris Convention for the Protection of Industrial Property 1883 as amended several times or members of the WTO Agreement or World Trade Organization In addition to having to fulfill the conditions of application requirements for mark registration, applications using priority rights This must be accompanied by proof of receipt of the application for registration of the first trademark which gives rise to the priority rights, which are translated into Indonesian by an sworn translator. Proof of priority rights in the form of a letter of application for registration with a receipt of the request, which also provides confirmation of the date of receipt of the request.

If the submitted form is a copy or photocopy of the letter or receipt, approval of the copy or photocopy of the letter or receipt is given by the Directorate General of Intellectual Property Rights if the application is submitted for the first time. After that, the Directorate General of Intellectual Property Rights will carry out an examination of the completeness of the registration requirements for the registered application. If in the inspection there are deficiencies in the completeness of the requirements for the application for mark registration, the Directorate General of Intellectual Property Rights requests that the completeness of these requirements be fulfilled within a maximum of 2 (two) months from the date of sending the request letter to fulfill the requirements.

Specifically in the case of deficiencies concerning the requirements for application for registration of marks with priority rights, the time period for fulfilling these requirements must be no more than 3 (three) months from the end of the period for submission of applications using priority rights. An application for registration of a mark is deemed 
withdrawn, if the required conditions are found not to be fulfilled within the specified time period as stated above. All fees that have been paid to the Directorate General cannot be withdrawn, even if the applicant or his proxy cancels the plan to register the mark.

\section{e. Legal Protection of Registered Trademarks}

Registered marks receive legal protection for a period of 10 (ten) years from the date of receipt of the mark registration and that period can be extended for the same period of 10 years. An application for an extension as referred to above may be submitted electronically or non-electronically in the Indonesian language by the owner of the Mark or his Proxy with a term of 6 months before the end of the period of protection for the registered mark and the extension referred to above shall incur an extension fee.

The purpose of the regulation related to the deadline for protection of registered marks for 10 years and can be extended is to ensure that the registered mark is actually used in the goods / services and the goods / services are still produced and / or traded and / or still on the market and are still distributed. In contrast, trademark law and geographical indications will not provide legal protection for brands that are only registered without having been used in production and / or trading activities. Therefore, the trademark law and geographical indications stipulate a number of requirements so that the application for renewal of registered marks can be approved by the Directorate General of Intellectual Property, Ministry of Law and Human Rights ("Ditjen KI"). Based on Article 36 of the trademark law and geographical indications, the application for extension is approved if:

1. The mark concerned is still used in goods or services as stated in the brand certificate; and

2. The goods or services as referred to in letter a are still produced and / or traded.

If these requirements are not met, the DG IPR will reject the application for renewal of the registered mark. In addition, the Minister of Law and Human Rights has the authority to delete the mark. Brand deletion can be done if:

1. Has something in common

2. Has similarity in principle and/or in whole with Geographical Indications

3. Contrary to state ideology, statutory regulations, morality, religion, decency, and public order; or

4. Have in common with all of them with traditional cultural expressions, intangible cultural heritage, or names or logos that are a hereditary tradition.

The deletion of a registered mark may also be submitted by a third party with an interest in the form of a lawsuit to the Commercial Court on the grounds that the mark has not been used for 3 (three) consecutive years in trade in goods and / or services from the date of registration or last use. Exceptions to these conditions are due to:

1. Import ban;

2. Prohibitions relating to permits for the circulation of goods using the Mark concerned or a decision from the competent authority that is temporary; or

3. Other similar prohibitions stipulated by Government Regulations 


\section{Conclusion}

The right of mark is a special right granted by the government to the brand owner, to use the mark or give permission to use it to others, the brand is very important in the world of marketing and advertising, therefore mark law and indications of geographic have a specific purpose related to the deadline for protection of registered marks for 10 years, the time limit which is considered short can be extended, the aim is to ensure that the registered mark is actually used in the goods / services and the goods / services are still produced and / or traded and / or still in market and still being distributed. In contrast, mark law and geographical indications will not provide legal protection for brands whose nature is to be registered only without having been used in production and / or trading activities.

Regarding the protection of registered marks, the period of time owned by registered marks owners is 10 years, and this can be extended with the aim of ensuring that the registered mark is still circulating in the market and still in the distribution process, related to the period given by the law. trademark and geographical indications seem too fast, although it can be extended, given that based on the mark rights the mark is a special right granted by the government to the brand owner, to use the mark or give permission to use it to others, ideally this special right must be had by the right holder at any time so that the registered mark owner can enjoy the rights to his mark forever.

\section{References}

Anonym, Apakah Logo Terdaftar Perusahaan Otomatis Menjadi Merek, melalui www.hukumonline.com, diakses Minggu, 5 Maret 2019, Pukul 22.55 wib.

Chazawi, Adami, Tindak pidanan Hak Atas Kekayaan Intelektual (HAKI), Banyumedia, Malang, 2007.

Djumhana, Muhammad dan M Djubaedillah, Hak Milik Intelektual: Sejarah, Teori dan Prkteknya di Indonesia, Bandung, PT. Citra Aditya Bakti, 1997, Halaman 160.

Gautama, Sudargo, Hukum Merek Indonesia, Bandung, PT Citra Aditya Bakti, 1989, Halaman 34.

Melalui: https://prasetyohp.wordpress.com/problematika-perlindungan-merek-di-indonesia/, Pada hari: Rabu, 24 januari 2019. Pukul 14-30.

Melalui: https://sulajadech.wordpress.com/2011/06/13/makalah-tentang-merk/, Pada hari: Rabu, 24 januari 2019. Pukul 14-30.

Melalui: https://www.hukumonline.com/klinik/detail/ulasan/lt4d176198f0e99/jangka-waktuhak-merek-dan-syarat-perpanjangannya, Pada hari jumat tanggal 23 januari 2019, pukul 20-00 WIB.

Prasetyo, G., Joebagio, H., Yamtinah, S. (2019). Modern Paradigm: Democratic Skills in a Higher Order Thinking Skills Frame. Budapest International Research and Critics Institute (BIRCI-Journal). 2(4); 150-159

Rahmi Jened Painduri Nasution, Interface Hukum Kekayaan Intelektual dan Hukum Persaingan Penyalahgunaan, HKI. PT. Raja Grafindo Persada, Jakarta, 2015.

Sutedi, Adrian, 2013, Hak Atas Kekayaan Intelektual. Jakarta: Sinar Grafika.

Tim Lindsey, et al (ed), 2011, Hak Kekayaan Intelektual Suatu Pengantar. Bandung: PT Alumni.

Tim Visi Yustisia, 2015, Panduan Resmi Hak Cipta dari Mendaftar, Melindungi, hingga Menyelesaikan Sengketa, Jakarta: Visimedia.

Tim Visi Yustisia, 2015, Panduan Resmi Hak Cipta, Visi Media, Jakarta. 